\title{
Comparative Analysis of Secretomes from Ectomycorrhizal Fungi with an Emphasis on Small-Secreted Proteins
}

\author{
Kevin Garcia ${ }^{1}$ and Jean-Michel Ané ${ }^{1,2 *}$ \\ ${ }^{1}$ Department of Bacteriology, University of Wisconsin-Madison, Madison, WI, USA, ${ }^{2}$ Department of Agronomy, University of \\ Wisconsin-Madison, Madison, WI, USA
}

Keywords: ectomycorrhizal, saprotrophs, secretomics, small-secretedproteins, symbiosis, secretomes

\section{A commentary on}

Comparative Analysis of Secretomes from Ectomycorrhizal Fungi with an Emphasis on Small-Secreted Proteins

by Pellegrin, C., Morin, E., Martin, F. M., and Veneault-Fourrey, C. (2016). Front. Microbiol. 6:1278. doi: $10.3389 /$ fmicb.2015.01278

Ectomycorrhizal (ECM) symbioses are major components of boreal and temperate forest ecosystems (Smith and Read, 2008; Clemmensen et al., 2013). Although well studied for several decades, very little is known about the molecular players involved in the establishment and maintenance of ECM symbioses (Garcia et al., 2015). Identifying the symbiont secretome is a promising way to dissect the fungal contribution to the mutualistic molecular dialog. Pellegrin et al.

OPEN ACCESS

Edited by:

Brigitte Mauch-Mani,

University of Neuchâtel, Switzerland

Reviewed by:

Maria J. Pozo,

Spanish National Research Council,

Spain

Paola Bonfante,

University of Turin, Italy

*Correspondence:

Jean-Michel Ané

jeanmichel.ane@wisc.edu

Received: 23 August 2016

Accepted: 17 October 2016

Published: 02 November 2016

Citation:

Garcia K and Ané J-M (2016) Comparative Analysis of Secretomes from Ectomycorrhizal Fungi with an Emphasis on Small-Secreted Proteins.

Front. Microbiol. 7:1734.

doi: 10.3389/fmicb.2016.01734
(2015) compared for the first time the predicted secretome of 49 soil-borne ECM, saprotrophic and pathogenic fungi, revealing shared and specific features between species, and providing a better understanding of the ECM lifestyle evolution.

\section{FUNGAL SECRETOMES SUPPORT THE SAPROTROPHIC-ECM FUNGI CONTINUUM}

Comparative genomic studies revealed that ECM fungi evolved multiple times from saprotrophic ancestors, and have partially lost their wood decay capabilities. This can be explained by the convergent loss of multiple lignin oxidoreductases, class II peroxidases and plant cell wall degradation enzymes (Martin et al., 2008, 2010; Tedersoo et al., 2010; Floudas et al., 2012; Wolfe et al., 2012; Kohler et al., 2015). The comparison of fungal secretome released by Pellegrin et al. (2015) supports this view.

Although features are shared between all studied fungi including the secreted lipases, proteases, and Small-Secreted Proteins (SSPs), ECM-specific features that support the transition toward a mutualistic lifestyle were highlighted. A reduction of Carbohydrate-Active enZymes (CAZymes) compared to other species was observed in ECM fungi, confirming a reduction of plant cell wall degradation capabilities.

Various SSPs called effectors are well known in pathogenic fungi to manipulate plant defenses to facilitate infection (Stergiopoulos and de Wit, 2009). Some SSPs with a similar activity were also described by functional analyses in mutualistic plant-fungal association (Kloppholz et al., 2011; Plett et al., 2011; Tsuzuki et al., 2016). More recently, a comparative in silico analysis revealed that many SSPs were shared by both arbuscular mycorrhizal fungi Rhizophagus clarus and Rhizophagus 
irregularis, supporting the role of secreted peptides in mycorrhizal associations (Sędzielewska Toro and Brachmann, 2016). Remarkably, Pellegrin et al. (2015) predicted more SSPs in the secretome of ECM than saprotrophic fungi, including many that are ECM-specific (17 clusters). This observation suggests that those specific SSPs could be a signature of the ECM symbiosis lifestyle and could play a predominant role in the molecular dialog with the host plants.

\section{CAN ECM-SPECIFIC SSPS BE INVOLVED IN EARLY STEPS OF MYCORRHIZAL SYMBIOSIS FORMATION?}

Mining the genome of the first ECM fungus, Laccaria bicolor, allowed the prediction of SSPs potentially involved in free-living conditions, mycorrhiza formation, or both (Martin et al., 2008). Later, SSPs have been identified in the secretome of the ECM fungi L. bicolor and Hebeloma cylindrosporum cultured without their host (Vincent et al., 2012; Doré et al., 2015). Pellegrin et al. (2015) predicted SSPs that are shared by ECM, saprotrophic, and pathogenic fungi, suggesting conserved mechanisms in hyphal development, fruiting body formation, or interaction with other soil organisms and the environment. Similarly, the prediction of ECM-specific SSPs suggests that they would be part of a molecular dialog with host plants, leading to the formation of functional ECM. So far, only fungal flavonoids and plant phytohormones were described in the early stages of ECM symbiosis establishment, but lipochitooligosaccharides, chitin oligomers and even SSPs could be hypothesized as part of this initial cross-talk too (Garcia et al., 2015).

Another function that could be attributed to fungal SSPs would be their involvement in host-specificity. Although a high degree of specificity is rare in ECM forests, some fungi can be found exclusively associated with few tree species (Churchland and Grayston, 2014). Thus, secreted molecules including SSPs could facilitate the establishment of such specific interactions. It is also possible to speculate that signaling molecules found in plant root exudates might trigger the expression of fungal SSPs, allowing the initiation of a specific interaction. The identification of thousands of SSPs from various ECM fungi combined with the development of transgenic transformation technologies will provide new insights on the molecular cues and signals participating in the establishment and function of ECM associations.

\section{REFERENCES}

Churchland, C., and Grayston, S. J. (2014). Specificity of plant-microbe interactions in the tree mycorrhizosphere biome and consequences for soil C cycling. Front. Microbiol. 5:261. doi: 10.3389/fmicb.2014.00261

Clemmensen, K. E., Bahr, A., Ovaskainen, O., Dahlberg, A., Ekblad, A., Wallander, H., et al. (2013). Roots and associated fungi drive longterm carbon sequestration in boreal forest. Science 339, 1615-1618. doi: 10.1126/science.1231923

Combier, J. P., Melayah, D., Raffier, C., Gay, G., and Marmeisse, R. (2003). Agrobacterium tumefaciens-mediated transformation as a tool for

\section{TOWARD THE VALIDATION OF ECM-SPECIFIC SMALL-SECRETED PROTEINS}

To this date, only one SSP named Mycorrhizal-induced SmallSecreted Protein 7 (MiSSP7) from L. bicolor was described in a symbiotic context. Pellegrin et al. (2015) and previous large-scale studies highlighted many other SSPs with unknown function (Martin et al., 2008; Doré et al., 2015; Kohler et al., 2015).

The generation of transgenic fungi affected in the expression of MiSSP7 was a turning point in the functional validation of ECM-specific SSPs. The down-regulation of MiSSP7 resulted in the inhibition of the Hartig net formation in poplar by interfering with jasmonic acid immune response (Plett et al., 2011, 2014). Excitingly, some other ECM fungi studied by Pellegrin et al. (2015) are also transformable including $H$. cylindrosporum (Combier et al., 2003) and Pisolithus tinctorius (RodríguezTovar et al., 2005). This technology opens the way to further systematic validations using RNA interference, CRISPR/Cas9, or over-expression approaches in both free-living and symbiotic conditions (Garcia et al., 2014; Xu et al., 2015). It is worth noting that $P$. tinctorius might become a particularly interesting model to understand the role of ECM-specific SSPs. Among the 17 ECM-specific SSP clusters, $P$. tinctorius SSPs were found in 12 of them.

Other approaches based on the host plant can also be envisioned to understand the role of ECM-specific SSPs including the application of purified SSPs on plant roots, or the ectopic expression of SSPs in genetically transformable hosts like poplar. Finally, identifying plant genes targeted by fungal SSPs using for example yeast-two-hybrid experiments will be ultimately needed to unravel the function of those small molecules in symbiotic associations.

\section{AUTHOR CONTRIBUTIONS}

The manuscript was written and edited by KG and J-MA.

\section{FUNDING}

KG was supported by a grant from the National Science Foundation (NSF-IOS\#1331098) to J-MA.

insertional mutagenesis in the symbiotic ectomycorrhizal fungus Hebeloma cylindrosporum. FEMS Microbiol. Lett. 220, 141-148.

Doré, J., Perraud, M., Dieryckx, C., Kohler, A., Morin, E., Henrissat, B., et al. (2015). Comparative genomics, proteomics and transcriptomics give new insight into the exoproteome of the basidiomycete Hebeloma cylindrosporum and its involvement in ectomycorrhizal symbiosis. New Phytol. 208, 1169-1187. doi: 10.1111/nph.13546

Floudas, D., Binder, M., Riley, R., Barry, K., Blanchette, R. A., Henrissat, B., et al. (2012). The Paleozoic origin of enzymatic lignin decomposition reconstructed from 31 fungal genomes. Science 336, 1715-1719. doi: 10.1126/science. 1221748 
Garcia, K., Delaux, P.-M., Cope, K. R., and Ané, J.-M. (2015). Molecular signals required for the establishment and maintenance of ectomycorrhizal symbioses. New Phytol. 208, 79-87. doi: 10.1111/nph.13423

Garcia, K., Delteil, A., Conéjéro, G., Becquer, A., Plassard, C., Sentenac, H., et al. (2014). Potassium nutrition of ectomycorrhizal Pinus pinaster: overexpression of the Hebeloma cylindrosporum HcTrk1 transporter affects the translocation of both $\mathrm{K}(+)$ and phosphorus in the host plant. New Phytol. 201, 951-960. doi: 10.1111/nph.12603

Kloppholz, S., Kuhn, H., and Requena, N. (2011). A secreted fungal effector of Glomus intraradices promotes symbiotic biotrophy. Curr. Biol. 21, 1204-1209. doi: 10.1016/j.cub.2011.06.044

Kohler, A., Kuo, A., Nagy, L. G., Morin, E., Barry, K. W., Buscot, F., et al. (2015). Convergent losses of decay mechanisms and rapid turnover of symbiosis genes in mycorrhizal mutualists. Nat. Genet. 47, 410-415. doi: 10.1038/ng.3223

Martin, F., Aerts, A., Ahrén, D., Brun, A., Danchin, E. G. J., Duchaussoy, F., et al. (2008). The genome of Laccaria bicolor provides insights into mycorrhizal symbiosis. Nature 452, 88-92. doi: 10.1038/nature06556

Martin, F., Kohler, A., Murat, C., Balestrini, R., Coutinho, P. M., Jaillon, O., et al. (2010). Perigord black truffle genome uncovers evolutionary origins and mechanisms of symbiosis. Nature 464, 1033-1038. doi: 10.1038/nature08867

Pellegrin, C., Morin, E., Martin, F. M., and Veneault-Fourrey, C. (2015). Comparative analysis of secretomes from ectomycorrhizal fungi with an emphasis on small-secreted proteins. Front. Microbiol. 6:1278. doi: 10.3389/fmicb.2015.01278

Plett, J. M., Daguerre, Y., Wittulsky, S., Vayssières, A., Deveau, A., Melton, S. J., et al. (2014). Effector MiSSP7 of the mutualistic fungus Laccaria bicolor stabilizes the Populus JAZ6 protein and represses jasmonic acid (JA) responsive genes. Proc. Natl. Acad. Sci. U.S.A. 111, 8299-8304. doi: 10.1073/pnas.1322671111

Plett, J. M., Kemppainen, M., Kale, S. D., Kohler, A., Legué, V., Brun, A., et al. (2011). A secreted effector protein of Laccaria bicolor is required for symbiosis development. Curr. Biol. 21, 1197-1203. doi: 10.1016/j.cub.2011.05.033

Rodríguez-Tovar, A. V., Ruiz-Medrano, R., Herrera-Martínez, A., BarreraFigueroa, B. E., Hidalgo-Lara, M. E., Reyes-Márquez, B. E., et al. (2005). Stable genetic transformation of the ectomycorrhizal fungus Pisolithus tinctorius. J. Microbiol. Methods 63, 45-54. doi: 10.1016/j.mimet.2005.02.016
Sędzielewska Toro, K., and Brachmann, A. (2016). The effector candidate repertoire of the arbuscular mycorrhizal fungus Rhizophagus clarus. BMC Genomics 17:101. doi: 10.1186/s12864-016-2422-y

Smith, S. E., and Read, D. (2008). Mycorrhizal Symbiosis, 3rd Edn. London: Academic Press.

Stergiopoulos, I., and de Wit, P. J. G. M. (2009). Fungal effector proteins. Annu. Rev. Phytopathol. 47, 233-263. doi: 10.1146/annurev.phyto.112408.132637

Tedersoo, L., May, T. W., and Smith, M. E. (2010). Ectomycorrhizal lifestyle in fungi: global diversity, distribution, and evolution of phylogenetic lineages. Mycorrhiza 20, 217-263. doi: 10.1007/s00572-009-0274-x

Tsuzuki, S., Handa, Y., Takeda, N., and Kawaguchi, M. (2016). Strigolactoneinduced putative secreted protein 1 is required for the establishment of symbiosis by the arbuscular mycorrhizal fungus Rhizophagus irregularis. Mol. Plant Microbe Interact. 29, 277-286. doi: 10.1094/MPMI-10-15-0234-R

Vincent, D., Kohler, A., Claverol, S., Solier, E., Joets, J., Gibon, J., et al. (2012). Secretome of the free-living mycelium from the ectomycorrhizal basidiomycete Laccaria bicolor. J. Proteome Res. 11, 157-171. doi: 10.1021/pr200895f

Wolfe, B. E., Tulloss, R. E., and Pringle, A. (2012). The irreversible loss of a decomposition pathway marks the single origin of an ectomycorrhizal symbiosis. PLoS ONE 7:e39597. doi: 10.1371/journal.pone. 0039597

Xu, H., Kemppainen, M., El Kayal, W., Lee, S. H., Pardo, A. G., Cooke, J. E. K., et al. (2015). Overexpression of Laccaria bicolor aquaporin JQ585595 alters root water transport properties in ectomycorrhizal white spruce (Picea glauca) seedlings. New Phytol. 205, 757-770. doi: 10.1111/nph.13098

Conflict of Interest Statement: The authors declare that the research was conducted in the absence of any commercial or financial relationships that could be construed as a potential conflict of interest.

Copyright (c) 2016 Garcia and Ané. This is an open-access article distributed under the terms of the Creative Commons Attribution License (CC BY). The use, distribution or reproduction in other forums is permitted, provided the original author(s) or licensor are credited and that the original publication in this journal is cited, in accordance with accepted academic practice. No use, distribution or reproduction is permitted which does not comply with these terms. 